\title{
3 The fear of states within the state
}

\section{John Locke and untrustworthy citizens}

The Englishman John Locke (1632-1704) wrote perhaps the most influential treatise in defence of toleration, and has also been seen as an early standard-bearer for religious freedom. A Letter Concerning Toleration was published in 1689, written, typically enough, in exile in the Netherlands after fleeing the Catholic King James II (1633-1701) and in the shadows of the ban on Protestantism imposed in France four years earlier. His opinion was that the Christian faith could not be promoted or defended through violence or coercion. He argued for a distinction between church and state and for widespread religious toleration: "I esteem that toleration to be the chief characteristical mark of the true church." ${ }^{1}$ Conviction, not persecution, was the way to redeem souls.

But at the same time, for Locke there were also limits to how far such toleration could go. If religions were immoral or represented a danger to the state, they could not be tolerated: "No opinions contrary to human society, or to those moral rules which are necessary to the preservation of civil society, are to be tolerated by the magistrate." ${ }^{2}$ The same was true for religious communities that attributed their patronage to and served a foreign power. Here he used Muslims as an example:

It is ridiculous for any one to profess himself to be a mahometan only in religion, but in every thing else a faithful subject to a christian magistrate, whilst at the same time he acknowledges himself bound to yield blind obedience to the mufti of Constantinople; who himself is entirely obedient to the Ottoman emperor, and frames the feigned oracles of that religion according to his pleasure. ${ }^{3}$

This reference to the mufti (Muslim jurisconsult) of Constantinople has been read as an image of a far more present and current institution - the pope in Rome even though Locke mentioned neither the pope nor Catholicism in this treatise. ${ }^{4}$ But the work must be interpreted in light of something he wrote earlier. In a letter

1 John Locke, “A Letter Concerning Toleration, being a Translation of Epistola de Tolerantia," in The Works of John Locke in Nine Volumes, 12th edn., vol. 5, no. 5 (London: Rivington, 1824 [1685]).

2 Locke,"A Letter Concerning Toleration," 45.

3 Locke,"A Letter Concerning Toleration," 47.

4 See for example David J. Lorenzo, "Tradition and Prudence in Locke's Exception to Toleration," American Journal of Political Science, vol. 47, no. 2 (2003) and Jeremy Waldron, God, Locke, and Equality: Christian Foundations in Locke's Political Thought (Cambridge: Cambridge University Press, 2002), 218.

Ә OpenAccess. (C) 2021 Frode Ulvund, published by De Gruyter. (cc) BY-NC-ND This work is licensed under the Creative Commons Attribution-NonCommercial-NoDerivatives 4.0 License. 
dating as far back as 1659 - to Henry Stubbe (1632-1676), the physician and social commentator who had great sympathy for toleration, - he articulated clear views on Catholics: ${ }^{5}$

The only scruple I have is how the liberty you grant the Papists can consist with the security of the nation (the end of government), since I cannot see how they can at the same time obey two different authorities carrying on contrary interest, especially where that which is destructive to ours is backed with an opinion of infallibility and holiness supposed by them to be immediately derived from God $[. ..]{ }^{6}$

In An Essay Concerning Toleration, written in 1687 but first published in the 1820s, he reiterated the same explicit charges against Catholics and was clear that "papists" ought not to be tolerated in society. This was primarily because Catholic states themselves denied toleration to other religious communities. ${ }^{7}$ That which does not tolerate, does not itself deserve to be tolerated. But most important was the political rationale, because Catholics were

[...] irreconcileable enemys of whose fidelity you can never be securd, whilst they owe a blinde obedience to an infalible pope, who has the keys of their consciences tied to his girdle, \& can upon occasion dispense with all their oaths promises \& the obligations they have to their prince espetially being an heritick \& arme them to the disturbance of the government I think they ought not to enjoy the benefit of toleration. ${ }^{8}$

It was thus through their alleged loyalty to the pope in Rome, and not to the states in which they resided, that Catholics rendered themselves politically untrustworthy citizens. In addition to religious communities loyal to foreign powers, neither would Locke tolerate atheists. Because they could not invoke a divine guarantor for their words, their swearing of oaths lacked credibility. This made them unreliable, and as such they could not be accepted as citizens.

5 Nabil Matar, “Introduction: The 'Copernican Revolution' of Henry Stubbe,” in Henry Stubbe and the Beginnings of Islam: The Originall \& Progress of Mahometanism, ed. Nabil Matar (Columbia University Press, 2013).

6 John Locke, "Letter to S.H.," in The Political Writings of John Locke, ed. David Wootton (New York: Penguin, 1993), 138.

7 Philip Milton and J.R. Milton (eds), The Clarendon Edition of the Works of John Locke: An Essay Concerning Toleration: And Other Writings on Law and Politics, 1667-1683 (Oxford University Press, 2006). Quoted here from Oxford Scholarly Editions Online: 290, linje 18ff. (http://www. oxfordscholarlyeditions.com/view/10.1093/actrade/9780199575732.book.1/actrade9780199575732-div2-27, accessed 2 August 2016).

8 Milton and Milton, The Clarendon Edition of the Works of John Locke, 291, line $5 \mathrm{ff}$. 
The American colony of Carolina's Constitution of 1669 is associated with John Locke, and he is regarded as its central draftsman. The Constitution was characterised by religious toleration, but also illustrates the era's hierarchical understanding of religions and permissions for religious practices:

\footnotetext{
[...] Jews, heathens, and other dissenters from the purity of Christian religion may not be scared and kept at a distance from it, but, by having an opportunity of acquainting themselves with the truth and reasonableness of its doctrines, and the peaceableness and inoffensiveness of its professors, may, by good use and persuasion, and all those convincing methods of gentleness and meekness, suitable to the rules and design of the gospel, be won ever to embrace and unfeignedly receive the truth; therefore, any seven or more persons agreeing in any religion, shall constitute a church or profession, to which they shall give some name, to distinguish it from others. ${ }^{9}$
}

There was no doubt here that Christian faiths took precedence and were understood to represent a truth, and that the Christian majority had an obligation to attempt to persuade adherents of other faiths. Although the presence of atheists and non-Christians was tolerated, the Constitution placed restrictions on their right to organise. A prerequisite to organising was above all that they believed in God, that they were law-abiding, and that members of religious communities swore the oath in an acceptable manner. They also had to avoid irreverent or rebellious ways of speaking in any mention of the public authorities or political affairs concerning the colony. ${ }^{10}$ Toleration went a long way in the colony, but the thresholds for it were - in keeping with Locke - grounded in politics, not religion.

\section{Samuel Pufendorf - agitation or disobedience?}

Locke's contemporary, political philosopher Samuel Pufendorf, had a view of toleration that shared features with his own. Pufendorf's writings must also be read in light of the events in France after 1685. This applied particularly to De habitu religionis christianae ad vitam civilem ( $O f$ the Nature and Qualification of Religion in Relation to Civil Life) from 1687.

His point of departure was a secular one. The state was not founded for the sake of religion; its sole purpose was to ensure the security of its citizens. Reli-

9 The Fundamental Constitutions of Carolina: 1 March 1669, Article 97. Quoted here from The Avalon Project. Documents in Law, History and Diplomacy, Yale Law School. Lillian Goldman Law Library (https://avalon.law.yale.edu/17th_century/nc05.asp, accessed 20 July 2020). 10 The Fundamental Constitutions of Carolina: March 1, 1669, Article 100 and 103. 
gion was therefore an individual responsibility, while the responsibility of the state was to respect the right to the free exercise of religion. Pufendorf was negative towards the policy against the Huguenots in 1685, believing that the French king had overstepped the boundaries of his authority. He was therefore sympathetic to the opinion that rebellion against the monarch was in some cases legitimate. At the same time, as with Locke, Pufendorf was clear that there were limits to toleration. Those who wished to be tolerated within a state were obliged to live in peace and tranquillity, and, as "good citizens," they would not be able not preach doctrines that incited agitation or insubordination towards civil authorities. ${ }^{11}$ This was particularly important if such agitators were contemporaneously dependent on a foreign power. ${ }^{12}$

Pufendorf addressed the theme of a "state within the state" as early as 1667 in De statu imperii Germanici (The Present State of Germany), which was banned by the pope as anti-Catholic. The text was a critical assessment of the Holy Roman Empire. In it, Pufendorf referred to Catholic priests and monks as constituting a burden to the state since they were dependent on a sovereign who was not only installed beyond the bounds of the kingdom, but who was also its enduring enemy. Both of these amounted to a danger of becoming a state within the state, or "statum in media Republica," as he wrote in Latin. ${ }^{13}$

Locke and Pufendorf represented a moderate school of Enlightenment thinking, even when it came to toleration. ${ }^{14}$ As a representative of radical Enlightenment thought, their contemporary Pierre Bayle (1646-1706) went much further. He was a Protestant Huguenot in exile in the Netherlands, and argued for a toleration that was far more radical. It was not only Christians that had to be tolerated, but also Jews, Muslims and atheists.

11 Pufendorf, of the Nature and Qualification of Religion, 135.

12 Pufendorf, Of the Nature and Qualification of Religion, 143.

13 Samuel Pufendorf, [psevd. Severini de Monzambano]. De Statv Imperii Germanici. Geneve, 1668, 133. For the translation, see Samuel Pufendorf, [De statu Imperii Germanici. English] The present state of Germany/Samuel Pufendorf; translated by Edmund Bohun, 1696 in Natural Law and Enlightenment Classics, ed. Knud Haakonssen (Indianapolis: Liberty Fund, 2007), 205. 14 Jonathan Israel, Radical Enlightenment: Philosophy and the Making of Modernity 1650-1750 (Oxford: Oxford University Press, 2001) and Marlies Galenkamp, "Locke and Bayle on religius toleration," Erasmus Law Review, vol. 5, no. 1 (2012): 79 ff. 


\section{Ludvig Holberg - good people, bad citizens?}

It was the moderate line that received the greatest philosophical support throughout the 18th century, and the Danish-Norwegian professor and historian Ludvig Holberg (1684-1754) was clearly inspired by its representatives. Holberg held a prominent position among the general public of the Danish-Norwegian dual monarchy, and played a significant role in conveying new ideas and currents of thought to Scandinavia from abroad. Holberg referred to Locke's draft constitution for the colony of Carolina as a model of the policy of toleration, and his own reasoning largely follows Locke and Pufendorf. ${ }^{15}$ His method also consisted largely of compilation - that is, the reproduction of other writings, often without reference to sources. ${ }^{16}$

Holberg argued that conversion could not be accomplished by force. This would only lead to a semblance of conversion. It was as impossible to conquer heretics with "Whip and Cane" as it was to storm a fortress with syllogisms. This was, Holberg wrote, because "it is not the heretic Person's Body that should be converted, but his Mind, which no Lash and Cane can bring into subjection." ${ }^{17}$ One cannot force people to believe; only to say that they do believe.

Holberg distinguished between religious heretics and religious fanatics. ${ }^{18}$ While heretics could be persuaded by the word, fanatics had what they referred to as "Conscience and Divine Inspiration" instead of "Scripture, History, and natural Reason" as the foundation of their religious understanding. Religious fanatics, or "the illuminated" as he also called them, were the least liked of the sects, and "of all sects, those least convenient to live amongst in Societies. The illuminated People can be good People, but will never make good Citizens," ${ }^{19}$ in par-

15 See Brian Kjær Olesen, Monarchism, Religion, and Moral Philosophy: Ludvig Holberg and the Early Northern Enlightenment (PhD diss., European University Institute, 2016). See also the anthology E. Vinje and J.M. Sejersted, eds., Ludvig Holbergs naturrett (Oslo: Gyldendal Akademisk, 2012).

16 Kristoffer Schmidt, Ludvig Holbergs Heltehistorier-mellem moralfilosofi og historie (PhD diss., University of Copenhagen, 2014), 36. Holberg's method of compilation is also discussed in Knud Haakonsen and Sebastian Olden Jørgensen, Ludvig Holberg (1684-1754): Learning and Literature in the Nordic Enlightenment (London: Routledge, 2017). For his use of Pufendorf, see especially Knud Haakonssen, "Holberg's Law of Nature and Nations," in Haakonsen and Olden Jørgensen, Ludvig Holberg (1684-1754): Learning and Literature in the Nordic Enlightenment (London: Routledge, 2017), $59 \mathrm{ff}$.

17 Ludvig Holberg, Moralske Tanker: deelte udi 2 Tomos, Tom 1, Libr I. Epigr. 81 (Kiøbenhavn, 1744), 76.

18 Referred to by Holberg as "en Fanaticus" in the singular.

19 Ludvig Holberg, Moralske Tanker, 81. 
ticular due to their deficient loyalty to the secular authorities, and their willingness to set government regulations to one side: "Since no one who refuses to subscribe to Society's Laws without conditionalities can be incorporated into a Society."20

Willingness to obey God before people was well and good, but for Holberg the problem was that fanatics mistook God's will for their own. They confused "Conscience with Weakness of Mind, divine Inspiration with the Vapours, Constancy with Obstinacy, Fear of God with Melancholy."21 Sects who stood in opposition to the principle of obedience to the government, and thereby favoured their own conscience as law and guide before that of the state, were not to be tolerated. Nor ought they to be tolerated due to their fervour in demanding that the consciences of others align with their own.

Holberg cited Quakers and Anabaptists as specific examples of fanatics; the former due to their pacifism, the latter for their resistance to the death penalty. But he devoted most space to Catholics, and especially Jesuits. Similarly to Locke, he employed allegations that the Catholic Church was itself intolerant of "all other Christian Sects" and that because they "seek to propagate, by all evil Means, their Opinions in those Places they enjoy the Freedom to remain," the absence of toleration was warranted. Holberg further pointed to the morality of the Jesuits as disqualifying: "Those who maintain it a Virtue to put a Father to death in order to bring the Son under Obedience to the Pope, cannot protest against Harshness when their Citizenship is denied.”22 Here he stressed perhaps the most stereotypical idea surrounding the Jesuits - that the end justified the means.

Like Locke, Holberg was dismissive of atheists. Theoretical atheists, those who doubted the existence of God but who otherwise led an orderly life, could be tolerated. However, practising atheists, those who led a "depraved and ungodly Lifestyle" and therefore harboured neither hope for divine reward nor fear of divine punishment, could not be tolerated since they helped to "undermine the Foundations of civil Society."23 In addition, in his Jødiske Historie [Jewish History] from 1742, he denied that Jews could be "good Subjects," primarily because they were awaiting a new "Master" to bring "the Jewish dominion to the apex of the highest of glories." 24

20 Ludvig Holberg, Epistler. Tom. IV. Epistola CCCIII (Kiøbenhavn, 1749), $17 \mathrm{f.}$

21 Ludvig Holberg, Moralske Tanker, 81.

22 Ludvig Holberg, Moralske Tanker, $83 \mathrm{f}$.

23 Ludvig Holberg, Moralske Tanker, $84 \mathrm{ff}$.

24 Ludvig Holberg, Jødiske Historie. Tom. II (Kiøbenhavn, 1742), 439. 
With Holberg, the stipulation for being tolerated was thus being regarded as a good citizen, that one's religious practices or dogmas did not lead one in opposition to the laws of the state, and thereby that one would be considered disloyal. It was the political danger of dissenting sects that was a decisive condition for an absence of toleration, not individuals' religious damnation. A few years later, Holberg therefore grew receptive to the idea that Jews could be tolerated, as was actually the case in Denmark, even though theologically they were regarded as the "principal Enemies of Christendom" and far more heretic than, for example, Catholics. ${ }^{25}$ Jews could now be tolerated, according to Holberg, but obviously not integrated as good citizens and granted civil rights. In the 1750s this was extended also to encompass Muslims, because no one - regardless of religion - ought to be held to be "an unworthy Member of a Society" as long as he conducted himself as an honest subject and as a "virtuous Citizen."26

In his memoirs from 1743, Holberg pointed out that those who were excluded from the "Beneficence of Toleration" were only "those who laud Principles that oppose secular power." 27 In 1748, this political peril was exemplified by the Huguenots. Here, in contrast to Pufendorf, who viewed the Huguenot's agitations as legitimate, Holberg used them as an example of what could not be tolerated in a state. What could be stranger, Holberg wrote, than seeing a third or a quarter of the nation's subjects have certain cities, fortifications and soldiers at their disposal, their own parliaments and assemblies independent of the central power, and standing in union with nations that could be the enemies of the realm? Holberg expressed great sympathy for French attempts at centralisation in the 1600s that ended with the revocation of the Edict of Nantes (regarding Huguenots) in 1685. The edict had contributed towards "establishing an Independent State in the midst of the Kingdom," and it was the consequences of this that had motivated the Crown to "overthrow this malformed Establishment, of which grievous effects have been seen, and with which the Kingdom could not endure."28

25 Ludvig Holberg, Moralske Tanker, 84.

26 Ludvig Holberg, BARON LUD. HOLBERGS Epistler, Befattende Adskillige historiske, politiske, metaphysiske, moralske, philosophiske, Item Skiemtsomme Materier. Tomus V. Epistola 450 (Kiøbenhavn, 1754), $138 \mathrm{f}$.

27 Ludvig Holberg, Tredje levnedsbrev (København, 1743), 66. (http://holbergsskrifter.dk/hol berg-public/view?docId=levnedsbreve\%2FAdVir3_overs.page, accessed 18 October 2018).

28 Ludvig Holberg, Ludvig Holbergs Epistler, Befattende Adskillige historiske, politiske, metaphysiske, moralske, philosophiske, Item Skiemtsomme Materier, Deelte udi 2de Tomer. Tomus I. Epistel X (Kiøbenhavn, 1748), $54 \mathrm{f}$. 


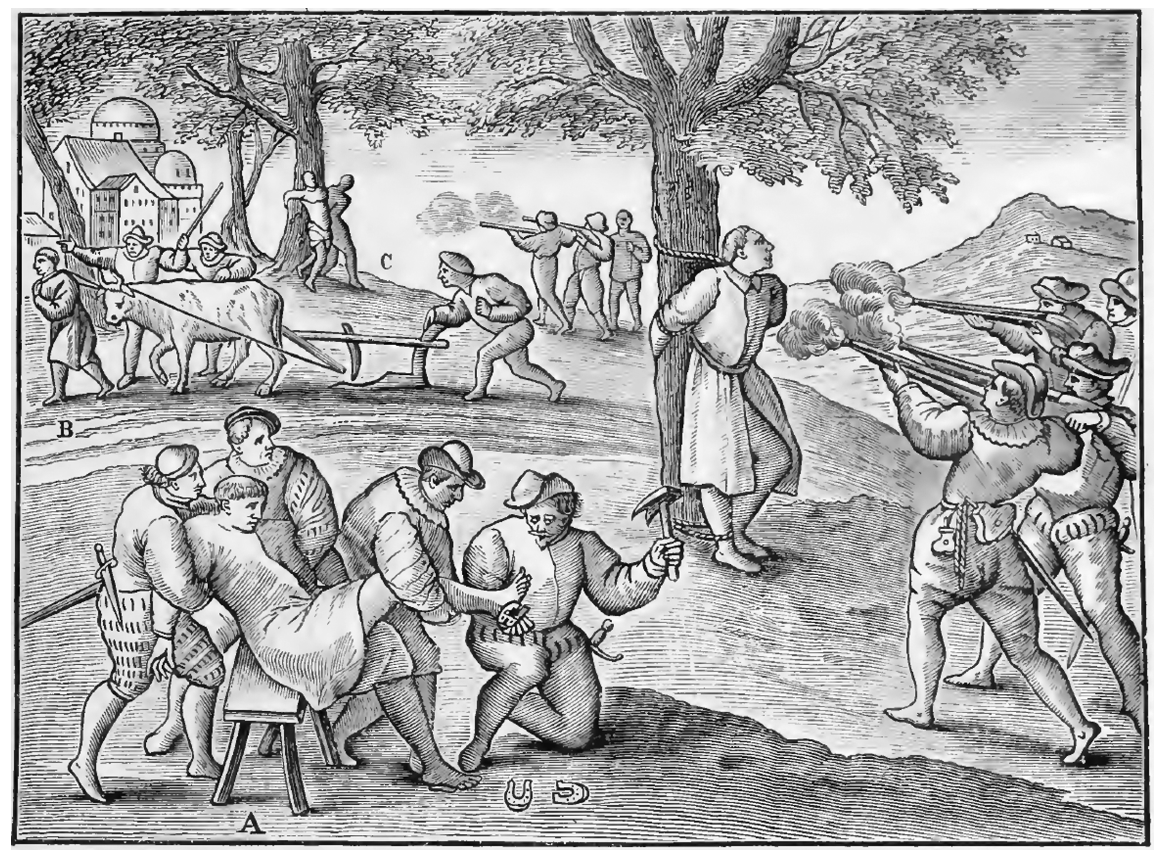

Figure 3.1: Richard Rowlands (c. 1550-1640) was baptised a Protestant, but later converted to Catholicism. In 1587, he published Theatrum Crudelitatum haereticorum nostri temporis (Theatre of the Cruelties of the Heretics of Our Time). It was a collection of grotesque copperplate engravings which were intended to depict crimes committed by heretics, primarily Huguenots, towards Catholics. The engravings were accompanied by detailed descriptions of the scenes in Latin and thus provided vivid portrayals of the Huguenots as dangerous and beyond state control. The book was republished in French several times from the 1880 s onwards.

Ludvig Holberg was important in the Scandinavian context since he reflected a European intellectual discussion about the limits of toleration. In this way, he helped to establish a framework for how this was discussed, especially among the Danish-Norwegian public and in the union's political bodies.

\section{"State within the state" as anti-republican slogan}

Locke never used the term "state within the state," unlike Pufendorf and Holberg, both of whom can be said to have used variants of it. However, what all of them had in common was that they took exception to circumstances that later came to characterise the term. To be a good citizen was to be loyal to secular authorities. Naturally, this also meant submitting to secular laws and provisions. 
Ideally, there was no room for parallel sovereignties within the state, with different assemblages of power and legal systems and with their own demands for obedience, in conflict with the interests of the sovereign. No corporation or institution ought to be able to lay claim to power or assert sovereignty in contradiction of the state's prerogatives or exclusive rights. This gradually became of particular importance as strong central powers emerged throughout the $1600 \mathrm{~s}$ and sovereignty was monopolised in state institutions - whether in republican, constitutional or absolutist forms. The state was understood to be sovereign and entirely independent of other authorities and power structures in society.

As historian Jacob Katz has shown in a classic portrayal of the history of the term "state within the state," there were also such factors as those to which the German Baron Jakob Friedrich von Bielfeld (1717-1779) referred in the first known definition of the term from 1760 (formulated in Latin as status in statu). ${ }^{29}$ Bielfeld also pointed out how dangerous it was for a sovereign state to permit other bodies, whether secular or ecclesiastical, any exercise of judicial or other power over parts of the population. This was to be reserved for the sovereign alone. ${ }^{30}$

The term was used regularly from the 1760s to describe the concessions granted to the Huguenots through the Edict of Nantes in 1598. In addition to being permitted to practise their religion, they also won control over the civil and military authority of their key cities, and along with this, in practice, a transfer of sovereignty.

However, the fact that the term was known and used in a relevant way long before Bielfeld defined it is evident from several French sources. Both Huguenots, Jansenists and Jesuits were associated or referred to as "estat dans l'estat" (state within the state) in French texts from the 17th century. ${ }^{31}$

29 Jacob Katz, "A State Within a State, the History of an Anti-Semitic Slogan,” in Jacob Katz, Emancipation and Assimilation: Studies in Modern Jewish History (Farnborough: Gregg International Publishers, 1972).

30 Baron de Bielfeld, Institutions politiques. I (The Hague, 1760), 29f. Quoted here from Katz, “A State within a State," 48.

31 Gaspard Froment, Advertissement povr les vniversitez de france, contre les iesvites (Paris, 1624), 3. (https://play.google.com/books/reader?id=t4p8bgq-QnYC\&printsec=frontcover\& output=reader\&hl=no\&pg=GBS.PA3, accessed 12 October 2016), Léonard de Marandé, Inconveniens d'Estat procedans du Jansenisme avec la refutation du mars francois de Monsieur Jansenius (Paris, 1654), 109 [http://gallica.bnf.fr/ark:/12148/bpt6k9601116s, accessed 12 October 2016]. See also Arthur Herman, "Protestant Churches in a Catholic Kingdom: Political Assemblies in the Thought of Philippe Duplessis-Mornay," The Sixteenth Century Journal, vol. 21, no. 4 (Winter 1990). 
In particular, the Nantes edict inspired an abundance of anti-Huguenot tracts on the Catholic side. This literature initiated "republicanism" as a politically charged term by associating it with anarchy, where the term "state within the state" was also in use. ${ }^{32}$ In the earliest example from 1612, accusations that the Huguenots wished to diminish the authority of the king and create "a state within the state" were substantiated by descriptions of garrisons, standing armies and separate political assemblies. ${ }^{33}$ This was followed up with descriptions of Huguenotic intrigue rooted in regional political assemblies and allegations that the Huguenots' rebellious nature was deliberately disguised in a Protestant political discourse emphasising devotion and loyalty to the Crown. ${ }^{34}$

From 1596 on, Maximilien de Béthune (1560 - 1641), later known as the Duke of Sully, was central in King Henry IV's council. Henry had been a Protestant before converting to Catholicism in order to assume the French crown, and Béthune was also a Protestant. He became an effective architect of the King's centralisation plans, not least through a reform of the tax system. In this context, regional parliaments were vital. He wrote his memoirs, which are certainly not recognised as historically correct in every respect, in the period after his retirement in 1611. The first two volumes were published in the 1640s while he was still alive, the latter two posthumously in the 1660s. In them, Béthune recalled a meeting with the congregation of Huguenotic Rouen in 1596. The Huguenots were willing to reform, but wanted to retain half of the tax revenues for themselves. Béthune described how the King's financial council received the proposal with indignation and anger, and that they claimed it would involve the formation of "vn Estat dans l'Estat" and the creation of two Crowns. He also explained that the king himself initially concurred with this understanding. ${ }^{35}$

In the spirit of the expression, France's strongman of the mid-1620s, Cardinal Richelieu (1585-1642), argued for the repeal of the Nantes edict. The same can be said of his views on the Jesuits, but he never used the term directly. ${ }^{36}$ Nor did

32 Arthur Herman, "The Huguenot Republic and Antirepublicanism in Seventeenth-Century France," Journal of the History of Ideas, vol. 53, no. 2 (Apr.-Jun. 1992), 250 ff.; Jeffrey K. Sawyer, Printed Poison. Pamphlet Propaganda, Faction Politics, and the Public Sphere in Early Seventeenth-Century France (Berkely: University of California Press, 1990), $116 \mathrm{ff}$.

33 Le Magot Genevois: Descouuert és Arrests du Synode national des Ministres reformez tenu à Priuas, l'an mil six cens douze (1612): 97. (http://cdm15999.contentdm.oclc.org/cdm/ref/collec tion/FrenchPolPa/id/32044, accessed 12 October 2016), Euvres complètes de Théodore Agrippa d'Aubigné, vol. 2 (Paris: A. Lemerre, 1877), 74 (Le Caducee ou L’Angee de Paix, datert 1612). 34 Herman, "The Huguenot Republic," 265.

35 Maximilien de Béthune Sully, Memoires Ov Oeconomies Royales D’Estat, Domestiqves, Politiqves Et Militaires De Henry Le Grand; Vol. 1, No. 2. (Paris: Billaine, 1663), 803.

36 Katz, "A State Within a State," $51 \mathrm{f}$. 
Louis XIV ever use the term as a justification for revoking the Huguenots' religious licence - but others did.

In Elie Benoist's (1640 - 1728) multi-volume presentation of the history of the edict between 1693 and 1695, i.e. a few years after its repeal, the term ("Etat dans l'Etat") was used several times. He referred to grievances from earlier in the century that the religion of the Huguenots had led to factionalism, that they desired a state within the state, and that they could elude ordinary legislation through special privileges. ${ }^{37}$ Himself a Huguenot pastor in France prior to the repeal, Benoist wrote his history in Dutch exile. ${ }^{38}$ In it, he also lambasted the notion that the Huguenots "formed a state within the state, with their own cities, own laws and own interests, politically at odds with the good of the kingdom." 39 Instead, he argued that the Huguenots' armed opposition to central power was a legitimate use of the right to rebellion, as had Pufendorf. ${ }^{40}$ His account is therefore an example of the fact that Huguenots themselves perceived claims of their constituting a state within the state as a central justification for the revocation of the edict, but also that these claims were rejected as baseless.

In his diary, the Duke of Saint-Simon, Louis de Rouvroy (1675-1755), asserted that claims of the existence of a state within the state were the grounds for the repeal of the edict. Three decades after its revocation (in 1716), he used the term explicitly as a description of the Huguenot's structure, but also to explain the king's motivation for the retraction. He explained that after 1598, the Huguenots had established a republican form of government with their own garrisons, troops, authorities, diplomats, and courts that even convicted Catholics, "in short, constituting a state within a state (un État dans un État)" that was willing to take up arms against the French king, and that was therefore enormously dangerous to the state. ${ }^{41}$ Furthermore, the duke explained that the king's advisers

37 Elie Benoist, Histoire de l'Edit de Nantes, contenant les choses les plus remarquables qui se sont passées en France avant \& après sa publication, à l'occasion de la diversité des religions : et principalement les contraventions, inexecutions, chicanes, artifices, violences, \& autres injustices, que les reformez se plaignent d'y avoir souffertes, jusques à l'Edit de révocation, en octobre 1685. Avec ce qui a suivi ce nouvel Edit jusques à présents. Tome premier (Delft, 1693), 134 and 301. (https://play.google.com/store/books/details?id=bHG_vzj1iu0C\&rdid=book-bHG_ vzj1iu0C\&rdot=1, accessed 12 October 2016).

38 Charles Johnston, "Elie Benoist, Historian of the Edict of Nantes," Church History, vol. 55, no. 4 (December 1986).

39 Elie Benoist, Histoire de L'Edit de Nantes, Tome Second (Delft, 1693), Preface.

40 Benoist, Histoire de L'Edit de Nantes. Tome Second, Preface. See also Johnston, "Elie Benoist," 479.

41 Duc Saint-Simon, Mémoires complets et authentiques du duc de Saint-Simon sur le siècle de Louis XIV et la régence. Tome Quatorzième. (Paris, 1829), 156. From author's translation into Nor- 
had portrayed the Huguenots "in the darkest of colours; as a state within the state" that undermined the king's sovereignty, an argument that, according to the duke, must therefore have motivated the king to repeal the Nantes edict. ${ }^{42}$

The term was also used in completely different contexts; among other things, the major trading companies were understood to constitute states within the state. In the French Dictionnaire Universel from 1701, the trading companies were mentioned under the term "Compagnie" with an elaboration that they declared war and settled peace, dispatched ambassadors, equipped fleets and armed forces, all completely independently of the state. According to the lexicon, the companies were "a state within the state, and a republic within the republic." 43

There is no doubt that in the examples from the 17th century, the term was used with a modern lexical meaning and encompassed the definition provided by Bielfeld in the 1760s. For a long time, however, there were only scattered examples, and the term cannot be said to have had any impact as a political slogan. Indeed, it was absent in a number of pamphlets and publications in connection with the repeal of the Edict of Nantes, in a case where one might expect that it would have been deliberately put to use.

\section{"State within the state" as anti-feudal slogan}

Katz has shown how the term quickly acquired broad usage among the public in the 1760s, and how it emerged precisely as a political slogan, used in an agitatorial sense due to the associations it evidently provided. The usage of the term "state within the state" rapidly became a habitual means to characterise a number of institutions that were perceived to be encroaching on the domains of the sovereign. Soon this came to apply to Jesuits, who were being excluded from many countries at around the same time. In 1773, the pope disbanded the order - an act, according to Katz, that was generally justified at the time by

wegian. See also Geoffrey Adams, The Huguenots and French Opinion 1685-1787: The Enlightenment debate on toleration (Waterloo, ONT: Wilfred Laurier University Press, 1991), 39.

42 Duc Saint-Simon, Mémoires de Mr. le duc de S. Simon ou l'observateur véridique, sur le règne de Louis XIV et sur les premières époques des règnes suivans. Seconde Edition. Tome Premier (London, 1789), 161. From author's translation into Norwegian.

43 Antoine Furetière, Dictionnaire Universel: Contenant généralement tous les Mots François tant vieux que modernes, \& les Termes des Sciences Et Des Arts ...(Leers, 1701), “Compagnie.” From author's translation into Norwegian. 
the allegation that they constituted a state within the state. ${ }^{44}$ Freemasons were also quickly identified as an example of this.

It is not unreasonable to assume that the term's breakthrough in the 1760 s may be related to it being decoupled from its anti-republican origins and adapted as an anti-feudal and anti-corporative slogan directed towards supporters of the absolute monarchy and aristocracy. In the history of the concept, state is also closely linked to estate, and until the 19th century the term could be used both for power structures in the modern sense of state and as a reference to privileged social groups (estates). ${ }^{45}$ "State within the state" could thus also be definitively understood as an estate in conflict for sovereignty against the monarchy (estate within the state).

The Age of Enlightenment was characterised by the focus on the individual, and corporative structures thus came under pressure. The pre-revolutionary society of estates had been founded precisely on various corporations and collective privileges, rights, and obligations. In many cases, these were corporations with a high degree of autonomy, and the guilds can often be identified as the classic example of the society of estates' corporate institution. The Encyclopédistes in France argued for the state's exclusive right to sovereignty, and in their publications criticised all manner of corporations that interfered with individual freedoms, with or without the blessing of the state. ${ }^{46}$ It was not merely Jesuits and Freemasons, but also a range of other associations, that held key positions in pre-revolutionary Europe.

Republicanism was viewed as the antithesis of the monarchical political system, and in particular to absolutism and the principle that power should be manifested in one person. ${ }^{47}$ We shall see that in the latter part of the 18th century, "state within the state" became an essentially derogatory way of branding anti-republicanism or structures that were understood to be in conflict with the principles of sovereignty of the people. As such, the application of the term was reversed: From being a slogan of anti-republicans in support of the French sov-

44 Katz, “A State Within a State,” 53.

45 Werner Conze and Reinhart Koselleck, "Staat und Souveränität," I-III in Geschichtliche Grundbegriffe: Historisches Lexikon Zur Politisch-sozialen Sprache in Deutschland, vol. 6, ed. Otto Brunner, Werner Conze and Reinhart Koselleck (Stuttgart: Klett-Cotta, 1990); Reinhart Koselleck, “A Response to Comments on the Geschictliche Grundbegriffe," in The Meanings of Historical Terms and Concepts: New Studies on Begriffsgeschichte, ed. Detlef Junker et al. Occasional Paper no. 15 (Washington DC: German Historical Institute, 1996), 65.

46 Katz, "A State Within a State," 52f

47 Herman, “The Huguenot Republic,” $249 \mathrm{ff}$. 
ereign and his monarchy, it grew into an anti-feudal slogan aimed at the foundations of the monarchy.

In the wake of the French Revolution, the concept became first and foremost an anti-Semitic slogan, and perhaps the most potent and animated remonstration to granting civil rights to Jews. This was almost a by-product of the symbolic use of Jews as a state within the state in order to bolster descriptions of other states within the state - the church, the military and, in particular, the aristocracy - all of which had initially been designated as more problematic.

The historian Jonathan Karp has discussed how the concept and the understanding of it legitimised the aggressive attack on the aristocracy during the French Revolution, and precisely how the binding of it to Jews became a rhetorical expedient, part of an arsenal of arguments hurled at the aristocracy to underscore its useless and parasitic nature. ${ }^{48}$ Emmanuel-Joseph Sieyès (1748-1836) issued perhaps the most influential pamphlet during the French Revolution. What is the Third Estate? (Qu'est-ce que le tiers-état?) was published in the opening stages of the revolution, in January 1789, and reappeared later the same year in new and greatly expanded editions. This occurred at a point when the aristocracy still had a certain grip on the rebellion against the French monarch. At the same time, however, antagonisms between the estates had now escalated. It had been decided the previous summer that the Estates General would be convened for the first time since 1614. At that time, the assembly reflected the society of the estates, and was divided according to estate, where each estate had one vote.

The political consensus among the bourgeoisie and aristocracy, anchored in shared incriminations against royal despotism, was destroyed in the autumn of 1788 when the aristocratic parliament in Paris agreed to uphold the structure from 1614. This allowed the privileged estates - the nobility and the clergy to be able to control the assembly. The rest of the population, referred to as the Third Estate, could thus be outmanoeuvred. The journalist Mallet du Pan (1749-1800) described the mood in January 1789. The debate was no longer characterised by discourses on king, despotism and constitution, he explained. Now it was "war between the Third Estate and the other two orders."49

In fierce terms, Sieyès's attacked the aristocracy's corporative grip on society in general, and the Estates General in particular. He argued that the Third Estate not only represented the people, but that it constituted a "complete nation.” The

48 Jonathan Karp, The Politics of Jewish Commerce: Economic Thought and Emancipation in Europe, 1638-1848 (Cambridge: Cambridge University Press, 2008), $135 \mathrm{ff}$

49 Quoted here from Georges Lefebvre, The French Revolution: From Its Origins to 1793 (New York: Routledge \& K. Paul, 1962), 98. 
Third Estate was therefore synonymous with the nation. The aristocracy, on the other hand, stood apart from it - or rather, constituted a nation within the nation. His rationale was especially grounded in an understanding, or assertion, of what productivity and utility really were. ${ }^{50}$ The Third Estate did all the real work in society, and stood for everything that was useful, while the aristocracy as an estate radiated in its own idleness, surrounded by a productive society. And not only that: the unproductive estates almost conspired to control resources they themselves had not contributed towards creating. It rendered them foreigners to the nation: "Such a class, surely, is foreign to the nation because of its idleness." 51

The aristocracy was foreign to the nation both because its power was illegitimate to the people and because the aristocrats had private self-interest, not the common good, as their aim. As such they were a burden, a parasitic organism corroding the nation. A nation, explained Sieyès, was an association of people under one law and represented by the same legislative assembly. The aristocracy, with its civil and political privileges, singled itself out from the people and the nation. This, Sieyès continued, therefore rendered the aristocracy a people apart within the nation - a state within the state: "It is truly imperium in imperio." 52

Sieyes's representation of the aristocracy had two natural outcomes. Either the privileged estate, motivated by a new and more social interest, ensured their own regeneration as useful citizens among the Third Estate through habituation to productive activity, or so had to be denied its continued existence as a state within the state and consequently expelled from society. The choice was between assimilation and exclusion. In practical terms, this was reflected in the self-proclaimed transformation of the Third Estate within the Estates General into a constituent assembly in the summer of 1789. They perceived themselves as representatives of a complete nation and demanded that the other two estates join them. In August of the same year, the National Assembly abolished core parts of the nobility's old privileges, thus staking out the regeneration of the nobility and its assimilation into the Third Estate as a response to Sieyès's alternatives.

In Germany, Sieyès had an attentive reader in Johan Gottlieb Fichte (17621814). In his apologia for the French Revolution of 1793, Beitrag zur Berichtigung der Urtheile des Publikums über die französische Revolution [Contribution to the

50 Karp, The Politics of Jewish Commerce, 136.

51 Quoted here from Oliver W. Lembcke and Florian Weber, Emmanuel Joseph Sieyès: The Essential Political Writings (Leiden: Brill, 2014), 47. See also Karp, The Politics of Jewish Commerce, 140. 52 Lembcke and Weber, Emmanuel Joseph Sieyès, 47; Karp, The Politics of Jewish Commerce, 143. 


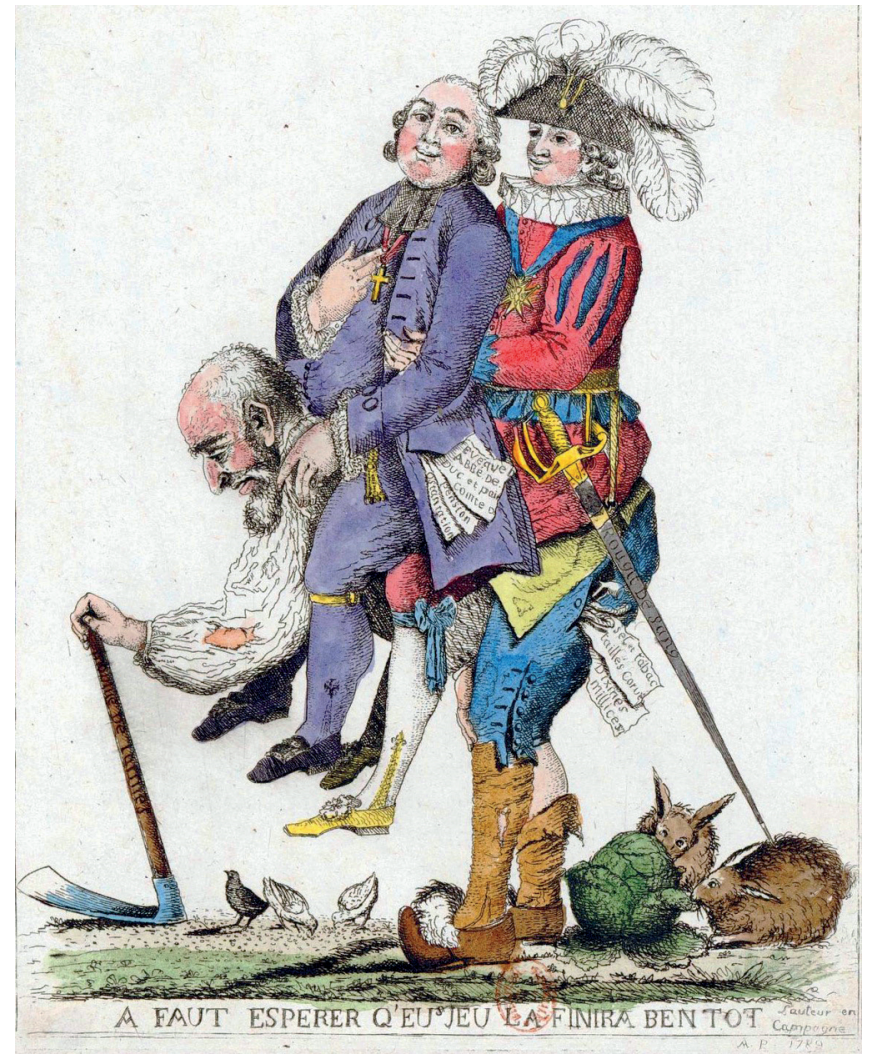

Figure 3.2: "We have to hope that the game will end soon: the author in the countryside." The clergy and nobility carried by the Third Estate. A French cartoon from 1789. In his influential pamphlet What is the Third Estate, Emmanuel-Joseph Sieyès argued that the nobility was foreign to the nation on account of its parasitic idleness, and that a regeneration and an inurement to productive work was necessary in order to avoid exclusion from the nation. Sieyès, and later Fichte, thus depicted the nobility in accordance with an anti-citizenship.

Rectification of the Public's Judgment of the French Revolution], he spent three of three hundred pages discussing Jews. He was not the first to label Jews as representatives of a state within the state, but to a considerable extent these few pages facilitated the association of the term with Jews in particular.

Fichte supervised the translation of Sieyès's polemic into German, and in many ways his own apologia was based upon it. Unlike Sieyès, however, Fichte was receptive to the idea that secession from the state, with the consequent for- 
mation of a state within the state, could be a legitimate outcome of a revision of the social contract. ${ }^{53}$ This was in keeping with the traditional right to rebellion and in line with Pufendorf, but he made sharp distinctions between legitimate and illegitimate states within the state. The definition of an illegitimate state within the state was first and foremost the extent to which members of associations were subject to their own jurisdictions, constitutions and normative codes, and especially if this gave them a kind of special privilege to discredit other groups in society without legal consequence. That being the case, this would be an expression of corporative despotism. ${ }^{54}$

For Fichte, the nobility was a despotic corporation that represented a danger to the common good. It was an estate that maintained and defended special interests and a distinctive morality, and was therefore "a dangerous state within the state," also understood in his time as an "estate within the state." $55 \mathrm{He}$ also cited the church, the guilds and the military as specific examples of such states within the state: "All of these are states within the state that not only have distinct interests, but interests that come in direct conflict with the interests of all other citizens." 56

Taken as a whole, it was a broad attack on the structures of L'Ancien Regime, and like Sieyès, he struck out vigorously at the aristocracy as beneficiaries of a greedy and gluttonous regime governed by self-interest.

But where Sieyès posited the Third Estate - and thus the bourgeoisie - as a productive and socially useful contrast to the parasitic aristocracy, Fichte primarily criticised the aristocracy's dominant position as property owners. In this regard, Jews were described as supporters of an aristocratic hegemony by exercising commercial functions on their behalf. In a later publication, Der geschlossene Handelsstaat [The Closed Commercial State] from 1800, the aristocracy was portrayed as masters of private property and the free market. Fichte thus branded the aristocracy not only as an unproductive class or group, but also associated it with an emergent capitalism with obvious negative connotations. Like Sieyès, Fichte also expressed disapproval of greed and selfishness, and of how self-in-

53 Karp, The Politics of Jewish Commerce, 153.

54 Karp, The Politics of Jewish Commerce, 155.

55 Johann Gottfried Fichte, Beitrag zur Berichtigung der Urtheile des Publikums über die französische Revolution. Erster Theil (1793), 195 ("so erhält dieser Stand ein abgesondertes Interesse, und eine abgesonderte Moral, und wird ein gefährlicher Staat im Staate").

56 Fichte, Beitrag zur Berichtigung, 196 ("Alle dieses sind ja Staaten im Staate, die nicht nur ein abgesondertes, sondern ein allen übrigen Bürgern entgegensetztes Interesse haben”). 
terest and the moral and commercial activities of certain groups came into conflict with the common good. ${ }^{57}$

\section{Nobles and Jews as "parasitic twins"}

Fichte associated Jews with the aristocracy, and both groups became representatives of what was unproductive and parasitic in society. Jonathan Karp maintains that the original coupling of market forces and an aristocratic regime eventually created space for romantically oriented economists and historians to decouple the nobility from such negative feudal traits, imposing associations exclusively on Jews as practitioners of a harmful and selfish capitalism. ${ }^{58}$ As such, Jews assumed the role of the aristocracy as the main representatives of parasitic capitalism.

In the next chapter, we will examine the portrayal of Jews in more detail, and how Jews were collectively described as a political danger, as a state within the state, and therefore as unsuitable citizens of the states in which they resided. In this way, the question of toleration, assimilation or exclusion was actualised to the greatest degree. In the Norwegian context, this was especially true at Eidsvoll in 1814 and in the subsequent period. In the Swedish parliament, too, demands for the exclusion and limitation of the alleged Jewish danger to the Swedish nation received great support.

Vivid anti-Jewish stereotypes existed in all the Scandinavian countries. In public opinion, a range of long-established accusations were hurled at Jews, but political arguments about their deficient qualities as citizens, in particular, were raised in new ways. Objections against giving Jews right of entry or liberties were powerful and widespread. However, around 1814 the three Scandinavian countries chose different political responses. Norway opted to exclude Jews, Denmark attempted to assimilate them, while Sweden decided to continue a policy of segregation introduced in the 1780s. It was only in the 1830s, and especially in the 1840s, that descriptions of political danger lost their leverage as a legitimate and broadly recognised principal objection against the toleration of Jews in Christian states.

57 See also Isaac Nakhimovsky, The Closed Commercial State: Perpetual Peace and Commercial Society from Rousseau to Fichte (Princeton: Princeton University Press, 2011), 9.

58 Karp, The Politics of Jewish Commerce, 153. 